\title{
İLGİ EKİ HÂL EKİ MİDİR?
}

\author{
IS GENITIVE SUFFIX A CASE SUFFIX?
}

Şahap BULAK*

$\ddot{O} z$

İlgi ekinin hâl eki olup olmadığg konusunda dilciler arasında bir fikir birliği yoktur. Banguoğlu, Ergin, Korkmaz, Lübimov, Karaă̆aç, Hengirmen, Topaloğlu gibi dilciler ilgi ekini tereddütsüz hâl eklerinden sayarken Ediskun, Bilgegil, Gencan, Gülsevin, Buran, Delice, Demiray gibi dilciler ise bu eki, hâl eki olarak kabul etmezler. İlogi eki için yapılan tanımlar arasında fark olması, teriminin doğrudan "hâl eki" olarak kabul edilmesi ile işlevleri ve kategorik durumunun farkl tayin edilmesi bu sorunun kaynağını oluşturur. Bu konudaki fikir ayrılığının temeline inildiğinde sorunun tek yönlü bir sorun olmadiğ l; terim, tanım, işlevler ve kategorik durumdan oluşan bir sorunlar yumağından oluştuğu görülür.

Günümüzde bir gramer sorununa dönüşen ilgi ekinin hâl eki olup olmadığı konusu, bu çalışmayla tartışmaya açılmıştır. Söz konusu sorunun tartışılıp açıklığa kavuşturulması ve mahiyetinin ortaya konulması amacryla öncelikle dilcilerin bugüne kadar ilgi eki terimi, tanımı, işlevleri, özellikleri ve kategorik durumu hakkında ortaya koyduğu yaklaşımlar değerlendirilmiştir. Daha sonra bu yaklaşımların yeterli ve yetersiz yanları irdelenerek değerlendirmeler yapılmış ve isim çekim eklerinden ilgi ekinin hâl ekleri içerisinde değil, iyelik ekleriyle beraber "ismi isme bağlayan ekler" olarak özel bir kategori oluşturması gerektiği kanısına varılmıştır. Böylece bir yandan bu konudaki sorunun çözümüne katkı sağlanması, diğer yandan Türkçenin öğrenilmesi ve öğretilmesine dolaylı da olsa olumlu katkıda bulunulması amaçlanmıştır.

\section{Anahtar Kelimeler}

Türkiye Türkçesi, şekil bilgisi, ekler, çekim ekleri, hâl ekleri, ilgi eki.

\section{Abstract}

There is not a common consensus about whether genitive suffix is one of case suffixes. Linguists like Banguoğlu, Ergin, Korkmaz, Lübimov, Karaağaç, Hengirmen, and Topaloğlu regard genitive suffix as a case suffix at all while Ediskun, Bilgegil, Gencan, Gülsevin, Buran, Delice, and Demiray do not accept. Different descriptions of genitive suffix, the direct acceptance of the term as case suffix, and different functional and categorical case constitute the root of the problem. Detailed research shows that it is not a unilateral problem but a multilateral problem including problems regarding its term name, description, function, and categorical situation.

This study investigates the issue of whether genitive case is a case suffix or not. In order to reach a conclusion, the term, description, function, features, and categorical situations of genitive suffix that have been discussed by myriad linguists so far were evaluated. By evaluating pros and cons of the discussions made by linguists it was concluded that genitive suffix is not a case suffix but is a

Yrd. Doç. Dr., Siirt Üniversitesi Fen Edebiyat Fakültesi Türk Dili ve Edebiyatı Bölümü, sahapbulak@gmail.com 
noun-to-noun (a suffix that binds a noun to noun) suffix. Consequently, this study aimed to make a major contribution to the resolution of the problem and for the teaching of Turkish language.

\section{Keywords}

Turkey Turkish, morphology, suffixes, inflexional suffix, case suffix, genitive suffix. 


\section{GİRIŞ}

İlk olarak Aristo'nun "Poetika" sında Eski Yunanca bağlamında sözü edilen hâl kavramı, bu dildeki "düşen, uzaklaşan" anlamına gelen "ptotis" kelimesinin Latince karşıllğı olan "casus" kelimesine dayanır. Kaynağını Eski Yunancadan alan hâl kavramı, Latincedeki çalışmalarla biçimlenmiştir (Uzun 1998:108). Dünya dilleri, hâl kavramının olup olmaması bakımından farklılık gösterirler. Türkçe, Rusça, Arapça ve Almanca gibi birçok dilde hâl kavramı varken Fransızca ve Farsça gibi bazı dillerde yoktur. Hâl kategorisi bulunmayan dillerde hâl eklerinin işlevi, bazı ön ekler veya kelimelerin değişik dizilişleriyle karşılanır (Buran 1995:37).

Hâl kategorisi; sayı, şekil ve işleyiş bakımından da dillere göre farklılık gösterir. Örneğin Eski Slavcada beş, Rusçada altı, Arapçada üç, Fincede on altı, Gürcücede yirmi üç, Macarcada yirmiye yakın isim hâli vardır. Hâl eklerinin sayısı sadece dilden dile göre değil, bir dilin farklı lehçeleri ile eski dönemi ve yeni dönemi arasında da farklılık gösterebilir. Örneğin, asıl kaynağ Hint-Avrupa ana dili olan Eski Yunancada beş, Latincede altı hâl vardır. Eski Almancada sekiz, bugünkü Almancada dört hâl eki vardır (Kalkan 2006:23). Hâl kategorisi bulunan dillerden olan Türkçede hâl eklerinin sayısı tartışmalıdır. Yalın, yükleme/belirtme, yönelme, bulunma ve çıkma hâlleri hakkında bir fikir birliği varken diğer hâller için farklı görüşler ileri sürülmektedir ${ }^{1}$. Hakkında fikir birliği bulunmayan hâllerden olan ilgi hâlinin hâl olup olmadığ ve ekinin hâl eki olarak kabul edilip edilemeyeceği konusu günümüzde bir gramer sorunu hâline gelmiştir.

Türkçenin yazılı kaynaklarla takip edilebildiği döneminden bugüne kadar nazallık ve yuvarlaklaşma dişında bir değişikliğe uğramadan gelen ilgi eki, ekli ve eksiz olarak kullanılmaktadır. Ekli kullanımı, ünsüzle biten kelimelerden sonra "-In/-Un"; ünlü ile biten kelimelerden sonra ise, "-nIn/-nUn" şeklindedir. Ek, ilerleyici-uzak-yarım benzeşmeden dolayı birinci kişi zamirlerine "-im" şeklinde gelmektedir. Eksiz kullanımı ise, aralarında ilgi olan iki ismin yan yana getirilmesi şeklindedir. Ek bu şekliyle belirtisiz isim tamlamalarında kullanılır. Türkçenin ilk yazılı kaynaklarından itibaren tarihî gelişimi izlenebilen ilgi eki ile ilgili birtakım sorunlar bulunmaktadır. İlgi ekinin ünlü ile biten kelimelere geldiğinde ünsüzle başlaması, ekin başındaki /n/ ünsüzünün ekin aslî ünsüzü olup olmadığı tartışmasına yol açmış, fakat bugüne kadar çok tartışılmışsa da bu konuda genel kabul gören bir izah yapılamamıştır.

İlgi eki ile ilgili sorunlardan biri de bu ekin hâl eki olup olmadığı tartışmasıdır. Bu konuda dilciler arasında bir fikir birliği yoktur. Banguoğlu, Lübimov, Ergin, Korkmaz, Hengirmen, Topaloğlu gibi dilciler ilgi ekini tereddütsüz hâl eklerinden sayarken Gencan, Bilgegil, Ediskun, Demiray, Buran, Gülsevin gibi dilciler ise, bu eki hâl eki olarak kabul etmezler. Çoğu dilci, genellikle eserlerinde ilgi ekini kendi fikirleri doğrultusunda gramerin doğal akışı içinde, tanımını yaparak örnekleri sıralamakta ve bu ekin hâl eki olup olmadığı konusunda bir görüş belirtmeye gerek görmemektedir.

İlgi ekinin hâl eki olup olmadığı konusundaki fikir ayrılığının temeline inildiğinde bunun tek yönlü bir sorun olmadığı; terim, tanım, işlev ve kategorik durumdan oluşan bir sorunlar yumağından oluştuğu görülür. Bu sorunun parçalarını, İlgi ekinin farklı tanımlanması, teriminin doğrudan "hâl eki" şeklinde ifade edilmesi, işlevlerinin farklı değerlendirilmesi ve isim çekim ekleri içerisindeki yerinin farklı şekillerde tayin edilmesi oluşturur. Bu sorunun bir sebebi de ilgi ekinden değil, hâl eklerinin tanımından kaynaklanmaktadır. Dilcilerin ilgi ekinin

${ }^{1}$ Geniş bilgi için bakınız ( Buran 2011:379-380). 
terimi, tanımı, işlevleri ve kategorik durumuna farklı yaklaşımları, bir sonuçta birleşme yerine genellikle farklı sonuçlar doğurmuştur. Böylece ilgi eki ile ilgili tek bir sorun gibi görünen fakat irili ufaklı birkaç sorundan oluşan bu sorun, iç içe geçmiş sorunlar yumağı hâline gelmiş, çözümü de giderek zorlaşmıştır. Bu sebeple bu hususta doğru bir yargıya varabilmek için öncelikle söz konusu durumların açıklığa kavuşturulması gerekir.

Bugün ilgi ekinin kategorik durumunda, bu ekin hâl eki olup olmadığı konusundaki fikir ayrılığından kaynaklanan bir belirsizlik vardır. Bu belirsizlik giderilmediği takdirde bu konudaki fikir ayrılığı derinleşecek ve bu konu bir gramer sorunu olarak kalmaya devam edecektir. Söz konusu gramer sorunun çözümü, sebeplerinin ortadan kaldırılmasıyla mümkündür. Hâl eki tanımı ile ilgi eki terimi, tanımı, işlevleri ve kategorik durumunun tam ve doğru tayin edilememesinden kaynaklanan bu sorun, söz konusu sebepler tam ve doğru olarak ortaya konulduğunda çözülecektir.

Bu çalışmayla günümüzde bir gramer sorununa dönüşen ilgi ekinin hâl eki olup olmadığ konusu tartışmaya açılmıştır. Söz konusu sorunun tartışılarak mahiyetinin ortaya konulması için öncelikle dilcilerin bugüne kadar ilgi eki terimi, tanımı, işlevleri, özellikleri ve kategorik durumu hakkında ortaya koyduğu yaklaşımlar değerlendirilecektir. Daha sonra bu yaklaşımların benzer ve farklı yanları irdelenerek bu konuda çözüme yardımcı olacak bir kanıya varılmaya çalışılacak ve ilgi ekinin terimi, tanımı, işlevleri ve kategorik durumu hakkında var olan fikir ayrılığının ortadan kaldırılmasına katkı sunulacaktır. Böylece bir yandan bu konudaki sorunun çözümüne katkı sağlanacak diğer yandan Türkçenin öğrenilmesi ve öğretilmesine dolaylı da olsa katkıda bulunulacaktır.

\section{2. İlgi Eki Terimi}

Türkiye Türkçesinde ilgi eki için bugüne kadar birçok terim adı kullanılmıştır. Bu terim adlarının bazıları zamanla unutulurken bazıları ise kullanılmaya devam edilmektedir. Türk Dil Kurumu, ilgi eki için; 1934 yılında Türk Dili dergisinin 7. sayısında yayımlanan Gramer Istılahları'nda "bağlamlık"; 1942 yılında yayımlanan Felsefe ve Gramer Terimleri ve 1949 yılında yayımlanan Dilbilim Terimleri Sözlüğü'nde "-in hâli"; 2010'da yayımlanan Gramer Terimleri Sözlügü̈nde ise, "ilgi eki/ilgi durumu" terimini önermiştir². Buradan Türk Dil Kurumu'nun bu ek için çeşitli terimler önerdiği sonunda "ilgi eki/ilgi durumu" teriminde karar kıldığı anlaşılmaktadır.

Ahmet Cevat Emre (1945:293), “türlük düşüm”; Banguoğlu (1940:28), Bilgegil (2009:120), Ergin(1993:216) "genitif (hâli)"; Timurtaş (1964:51), Topaloğlu (1989:89), Korkmaz, (2010:129) "ilgi hâli/durumu"; Hatipoğlu (1972:116), Vardar (2002:190) ve Hengirmen (2007:125) "tamlayan durumu"; Lübimov (1959:408-412) "iyelik hâli"; Kahraman (2011:395) "belirten durumu"; Banguoğlu (2000:328) “katılma/kimin hâli” terimini kullanmaktadır. Banguoğlu, 1940 yılında yayımladığı "Ana Hatlarıyla Türk Grameri" adlı eserinde bu ek için "türlük düşüm" terimini kullanırken 1959 yılında yayımladığ 1 "Türk Grameri- Ses Bilgisi" adlı eserinde "genitif (hâli)"; 1974 yılında yayımladığı "Türkçenin Grameri" adlı eserinde ise "kimin/katılma hâli" terimini kullanmıştır.

İlgi ekinin tanımlanarak özellikleri, işlevleri ve kategorik durumunun doğru tayin edilebilmesi için bu ekin terim adlandırması çok önemlidir. Bugün söz konusu ek için dilciler değişik terim adları kullanmaktadır. Bu durum, hem ilgi ekinin tanımının yapılmasını zorlaştırmakta hem özellikleri, işlevleri ve kategorik durumunun belirlemesine engel teşkil

\footnotetext{
2 Söz konusu eserde "ilgi durumu" ve "ilgi eki" maddeleri peş peşe verilerek birbirine benzer ifadelerle tanımlanmıştır. Bu durum, bu iki terimin farklı anlamlar ifade ettiği görüntüsü verse de açıklamalarına bakıldığında ilgi ekinin hâl eki olarak kabul edildiği görülür (Korkmaz 2010:129).
} 
etmekte hem de öğrenilmesi ve öğretilmesini zorlaştırarak bu konuda bir karışıklık oluşturmaktadır. Bu terimin adlandırılmasında birlik sağlanması, ekin tanım, işlev ve kategorik durumunun belirlenmesi ile öğrenilmesi ve öğretilmesini de kolaylaştıracaktır.

Günümüzde söz konusu ek için kullanılan terim adlarından "ilgi eki" terimi yaygınlık kazanmıştır. Fakat bu terim, yabancı dil ve dilbilgisi kurallarının etkisiyle daha çok "ilgi hâli/durumu eki" şeklinde kullanılmaktadır. Sadece "ilgi hâli/durumu eki" teriminde değil, bunun dışındaki "belirten durumu", "tamlayan durumu", "-in hâli", "kimin hâli" ve "katılma hâli" gibi terimlerde de "hâl" ve "durum" kelimelerinin kullanılmış olmasından ilgi ekinin hâl eki olduğunun peşinen kabul edildiği ve bu durumun içselleştirildiği manası çıkar ki bu bilimsel bir yaklaşım değildir. İsmi fiile bağlayan ekler için "hâl/durum eki" tabiri kullanılması doğaldır. Ancak ismi isme bağlayan bir ek için bu tabirin kullanılması izah gerektirir. Mantığını açılamadan ilgi ekinin hâl eki olduğunu kabul etmek dile ve bilime hizmet etmez. Bugün dilcilerce hâl eki olarak kabul edilen dokuz ekten ${ }^{3}$ sadece bir tanesinin asıl işlevi, eklendiği isimleri isimlere bağlamaktır. Bu ek de ilgi ekidir. Diğer eklerin asıl işlevi ise, eklendiği isimleri fiile bağlamaktır. Hâl eki olmadığı ortada olan ilgi ekinin "ilgi hâli/durumu eki" terimi ile adlandırılması doğru değildir. Bu sebeple bu ek için yaygınlık kazanan "ilgi eki" terim adını kullanmak uygun bir yaklaşım olacaktır.

\section{3. İlgi Ekinin Tanımı}

Gramer kitapları ve konuyla ilgili yayınlarda yapılan ilgi eki tanımlarına bakıldığında bu tanımların hâl ekleri tanımıyla ilişkili olduğu göze çarpar. Dilciler, ilgi ekini hâl eki sayıp saymamalarına göre, genellikle önce hâl eki tanımını yapıp daha sonra ilgi eki tanımını da buna uydurmuşlardır. Bu sebeple hâl kavramı ve eklerinin doğru tanımlanması, ilgi ekinin tanımının yapılması ve kategorik durumunun belirlenmesi için çok önemlidir. Dilcilerin hâl ekleri tanımlarına bakıldığında yapılan tanımlar arasında bir fikir birliği olmadığı görülür. Bazı dilcilerce isim soylu kelimeleri yükleme bağlayan ek olarak tanımlanan hâl ekleri, bazı dilcilerce ismi isimlere yahut fiillere bağlayan ekler olarak tanımlanmaktadır.

Hâl kavramı, terim sözlükleri, dil bilgisi kitapları ve ilgili makalelerde; "İsmin cümle içinde bulunduğu dil bilgisi şekli; yalın veya eklerle genişletilmiş olarak aldığı geçici durum" (Korkmaz 2010:74), "Fiile doğrudan bağlanan fiili doğrudan ilgilendiren isimlerin bu bağlanma veya ilgi sirasında içinde bulundukları durum" (Buran 2011:380), "Bir ismin cümle içinde başka bir kelimeyle ilgi kurmak üzere veya ek alarak girdiği durum." (Topaloğlu 1989:81), "Tümce içinde adın görevini belirleyen, adın öteki sözcüklerle ilişkisini gösteren dil bilgisi ulamı" (Koç 1992:20), "Başka bir sözcükle ilgi kurmak üzere, adın, yalın olarak veya ek alarak bulunduğu durum" (Hatipoğlu 1972:10), "Adın tümcedeki işlevini gösteren, biçimsel değişimlerini ya da çekim eklerini belirten dil bilgisi ulamı" (Vardar 2002:84), "Cümlede özne, nesne, tümleç gibi konumlarda görünebilmek için adların aldığı sözdizimsel özellik" (Hengirmen 1999:11), "Cümledeki görevlerine ve fiille olan ilgilerine göre isimlerin bulunabilecekleri beş durumdan herbiri" (Ediskun 2010:110-113) gibi aşağı yukarı benzer şekillerde tanımlanmıştır.

Bazı dilciler ise hâl kavramını hâl ekleri bağlamında; "Durum eklerini anlam ve tür olarak değiş̧tirmeyen ancak sözdizimsel bir değer katıp, tümleç birimine dönüştüren ekler öbeği" Delice 2000:135-150), "Fiil ile tamlayıcı veya tamlayıcılar arasında ilişki kuran ekler" (Özkan 1999:125-143), "Ulandıkları adları, anlatımda kendilerinden sonra söylenen yüklemlere, çekim ilgeçlerine ya da başka adlara bağlama işlevi gören ekler" (Kahraman 2003:308-309), "Tümce içindeki isimleri diğer sözcüklere değişik anlam ilişkileri çerçevesinde bağlayan biçimbirimler" (Eker 2006:279-280), "İsme gelen isimle

Yalın hâl, ilgi hâli, belirtme hâli, yönelme hâli, bulunma hâli, çıkma hâli, vasıta hâli, eşitlik hâli ve yön gösterme hâli. (Buran 2011:380). 
isim ve isimle fiil arasında şekil ve anlam ilişkileri kuran ekler" (Özkan 2001:153-165) şeklinde tanımlamışlardır.

Bu tanımlara benzemekle beraber konuyu daha ayrıntılı ele alan dilciler de vardır. İsimlerin söz içinde başka kelimelerle olan ilişkilerine göre farklı hâllerde bulunduğunu belirten Banguoğlu, bu hâllerin kelimelere gelen eklerle belirtildiğini, farklı hâllere ismin hâlleri, bu hâlleri gösteren eklere ise isim çekimi dendiğini söyler (Banguoğlu, 2000:326-327). Hâl kavramının çoğu dillerde isimlerin biçim bakımından değişimi ve çekimi şeklinde belirdiğini söyleyen Aksan'a göre, cümlenin düzeni içinde isimlerin (ve kimi dillerde isim soylu öteki ögelerin) yüklendiği görevi belirleyen hâl kavramı, cümlede ismin sözdizimi açısından rolünü ve öteki öğelerle ilişkisini gösterir ve anlam açısından ona belli bir özellik yükler (Aksan 1998:90). Durum imlemesi, dilbilgisel ilişkileri belirlemekte temel unsur olduğundan hâl eklerinin bağlandıkları isim öbeği üzerinde işlevci görevi gördügünü söyleyen Bozşahin'e göre ise, eylemin özelliğine bağlı olan durum imlemesi açık olmadığında, sözcük dizimi dilbilgisel ilişkileri belirler. Sözcük dizimindeki esneklik, durum imlemesinin hangi dilbilgisi katmanınca yapıldığına göre değişir (Bozşahin 1997:61-69).

Hâl eklerini, isimleri çeşitli münasebetler için türlü hâllere sokan ekler olarak tanımlayan Ergin, ismin hâllerini ise ismin diğer kelimelerle münasebeti sırasında içinde bulunduğu durumlar olarak tanımlar. İsmin bu münasebetleri bazen eksiz olarak, fakat çoğu zaman da ek alarak ifade ettiğini söyleyen Ergin'e göre, hâl ekleri ismi isimlere, edatlara ve özellikle fiillere bağlayarak birçok ilişki kurar ve bu ilişkilerden birçok isim, edat ve fiil grupları ile cümleler doğar. Ancak hâl ekleri asıl olarak ismi fiile bağlayan eklerdir. Bu özelliği ile asıl çekim ekleri hâl ekleridir (Ergin 1993:226-228).

Ad öbeklerinin biçimbilimine bağlı olarak dil bilgisinde soyut durum ve soyut olmayan, daha teknik bir deyişle biçimbilimsel durum olmak üzere iki türlü durumu bulunduğunu söyleyen Uzun'a göre; bir soyut durum, belirli bir güdülenmeyle biçimbilimsel olarak da sunulabilir ama biçimbilimsel durum, her zaman biçimbilimsel olarak yansıtılan durumdur. Türkçede, iki soyut durum (yalın ve belirtme), üç biçimbilimsel durum (yönelme, kalma ve çıkma) bulunmaktadır. Belirtme durumu, ilgili ad öbeği anlambilimine bağlı olarak biçimbilimsel olarak da sunulmaktadır. Durum yüklemenin yönetime dayanması, yani ilgili ad öbeklerine durumların ancak yöneticileri tarafindan yüklenebilmesi, durum yüklemede yapısal bir yön bulunduğunu gösterir. Bununla birlikte, durum yüklenecek olan öğelerin ad öbeği olması ve bu ad öbeklerinin bir biçimde yönetiliyor olması, durum yükleme ile rol yükleme etkileşimine de zemin hazırlar, çünkü, rol ölçütünü gözeterek bütün ad öbeklerinin yöneticilerinden yalnızca durum değil, rol de almaları beklenir. Durum yüklenecek öbek bir ad öbeğidir ve ad öbekleri bir üye olarak rol yüklenmelidir (Uzun 1998:130).

Bütün bu tanım ve yorumlarda iki husus ön plana çıkmaktadır. Bunlardan biri, hâl eklerinin eklendiği isimleri fiillere bağlamaları, diğeri ise eklendiği kelimeleri isim ve fiillere bağlamalarıdır. Aslında hâl ekleri isimleri hem fiillere hem de isimlere bağlar. Yönelme, belirtme, bulunma, çıkma grubu gibi kısaltma grupları hâl ekleri yardımıyla kurulan kelime gruplarıdır. Hâl eklerinin buradaki işlevi ismi isme bağlamaktır. Fakat bu işlev, hâl eklerinin asıl işlevi değil, diğer işlevlerinden biridir. Hâl eklerinin asıl işlevi, isimleri fiile bağlamaktır. Eklerin kategorik durumunu belirleyen asıl işlevleridir. Yapılan tanımlarda bu hususlar vurgulandığı takdirde hâl kavramının kapsamı belirlenir ve bu kapsama giren ve girmeyen ekler daha doğru bir şekilde tespit edilebilir. Bütün bu veriler ışığında hâl kavramı, "fiile doğrudan bağlanan isimlerin bu bağlanma esnasında içinde bulundukları durum" şeklinde; hâl ekleri ise, "esas işlevi isimleri fiile bağlamak olan, aynı zamanda isimleri isimlere ve bazı edatlara bağlayan ekler" şeklinde tanımlanabilir. Hâl kavramı ve ekleri bu şekilde tanımlandığında ilgi eki, fiili 
doğrudan ilgilendirmediği ve esas işlevi isimleri fiile bağlamak olmadığı için hâl kapsamı dişında kalır.

Bugüne kadar dilciler tarafından birçok ilgi eki tanımı yapılmıştır. Bu tanımlarda ek, "İsmi tabi olduğu başka bir isme bağlayan ek" (Ergin 1993:218), "İsimlerin sahip olanı, tabi olunam ve kapsayan gösteren, dolayısıyla bir sahip olunanı, tabi olanı ve kapsanan gerektiren hâl" (Banguoğlu 2000:328), "Eklendiği adla başka bir adın arasında ilgi bağg kuran ad durumu" (Korkmaz 2003:23), "Adın ait olma durumunu gösteren durum." (Hengirmen 1999:352-353), "İsim tamlamalarında bir kavramın başka bir kavrama bağlandığını, onunla tamamlandığını gösteren hâl." (Topaloğlu 1989:89), "İsmin başka bir isimle ilgisi olduğunu ifade eden hâl." (Vural-Böler 2014:151), "İsmin başka bir isimle ilgisini kuran durum." (Özçelik- Erten 2000:116), "Tümcede iyelik ardılının gösterdiği iyeyi belirten birime eklenen, onu belirli kılan bir ardll." (Adalı 2004:72), "İsme belirtme, sahiplik, mensubiyet, ilgi vb. anlam kazandıran bir ek." (Karahan 1999:210), "Bir kavramın başka bir kavrama bağlandığımı, onunla bütünlendiğini gösteren durum." (Vardar 2002:109), "Adın bir başka kavramla ilişkisi, bağlantısı durumu" (Aksan 1998:92), "Ad görevindeki sözcü̈̆ün tasıdığı kavramın başka bir kavrama bağlanması durumu." (Hatipoğlu 1972:116) şeklinde tanımlanmıştır.

Dışarıdan bakıldığında aşağı yukarı benzer tanımlar olarak görülen bu tanımlar dikkatle incelendiğinde bunların farklı yaklaşımları yansıttığı görülür. Genellikle "ismi isme bağlayan ek" olarak tanımlanan ek, bazı dilcilerce "ismi başka bir kavrama bağlayan ek" veya "bir kavramın başka bir kavrama bağlandığım gösteren durum" şeklinde tanımlanmıştır. Bu farklı yaklaşımlar karışık bir durum ortaya çıkarmakta ve ilgi ekinin neye göre tanımlanması gerektiği konusunu ön plana çıkarmaktadır.

İlgi ekinin kategorik durumunu doğru tayin edebilmek için bu ekin belli kıstaslara göre bir tanımının yapılması gerekir. Böyle bir tanım yapıldığı takdirde ilgi ekinin hâl eki olup olmadığı konusunda daha doğru bir kanıya varılabilir. Yapılacak tanım, ilgi ekini tam olarak yansıtmalı ve hâl ile iyelik eklerini dışarda bırakmalıdır. İlgi eki; "esas işlevi eklendiği ismi kendisinden sonraki isimlere bağlamak olan, aynı zamanda bazı edatları zamirlere bağlayan isim çekim eki" şeklinde tanımlandığında hem ilgi ekini tam olarak ifade eder hem de hâl ve iyelik eklerini dışarıda bırakır. Çünkü hâl eklerinin esas işlevi isimleri kendisinden sonraki isimlere bağlamak değil, isimleri fiile bağlamaktır. İyelik ekleri ise, zamirleri edatlara bağlamaz.

\section{4. İlgi Ekinin İşlevleri}

Dışarıdan bakıldığında ilgi ekinin işlevleri konusunda dilciler arasında bir kabul birliği varmış gibi görünür ancak bu konuda yapılan değerlendirmeler ayrıntılı olarak incelendiğinde bu konuda farklı yaklaşımlara rastlanır. Gramer kitapları ve ilgi ekiyle ilgili yayınlar incelendiğinde dilcilerin ilgi ekinin iki işlevi konusunda hemfikir olduğu görülür. Bunlar:

1. İlgi eki, eklendiği ismi kendisinden sonraki isim veya isimlere bağlar. İlgi ekinin asıl işlevi olan bu işlev konusunda dilciler arasında fikir birliği vardır. Ek, bu işleviyle isim tamlaması, ilgi grubu ve deyimler kurar: Ali'nin defteri, sinffin arka kapısı, benim kitaplarım, sizin kız, benim sokak, onun bahçe, günün adamı, babasının oğlu gibi. İlgi eki, bu işlevde ekli olarak kullanıldığı gibi eksiz olarak da kullanılabilir: Bahçe kapısı, misafir odası, araba motoru, mutfak robotu gibi.

2. İlgi eki, zamirleri bazı edatlara bağlar. Bu işleviyle edat grubu kurar: senin için, onun gibi, sizin kadar, onun ile, şunun için, bunun kadar, senin ile, benim için gibi.

İlgi ekinin bu iki işlevi hakkında dilciler arasında bir fikir birliği vardır. Bu işlevler dışında ilgi ekinin ismi fiile bağlama işlevinin olduğunu söyleyen dilciler vardır (Ergin 1993:219; Banguoğlu 2000:328; Kahraman 2011:396; Vural-Böler 2014:151; Özçelik- Erten 2000:116 gibi). 
Fakat söz konusu dilcilerin bu işlev için verdiği "Güvercinler Durmuş'undur. Bu bahçe sütçününmüş. Kalem onundur. Mehmet'indir." gibi örnekler incelendiğinde, bu örneklerin ek fiil almış tamlananı düşmüş/düşürülmüş isim tamlamalarından oluştuğu görülür. Burada ilgi eki alan isim, aldığı ilgi ekiyle ek fiile değil, düşen tamlanana bağlanmıştır. Tamlanan düştüğü ya da düşürüldüğü için bu yapı, ismin ilgi ekiyle doğrudan ek fiile bağlandığı şeklinde bir görüntü vermektedir. Aslında bu kullanımlarda düşen bir isim unsuru vardır ve bu unsur göz ardı edilmektedir. Bunu, ilgi ekini hâl eki sayan dilcilerin bir kısmı da dile getirmektedir (Ergin 1993:219; Banguoğlu 2000:328; Kahraman 2011:396; Korkmaz 2003:270).

İlgi ekinin ismi fiile bağladığını savunan dilcilerden Ergin, bu işlev için verdiği "Orhan'ındır, senin olsun" örneklerini açıklarken aslında ilgi ekinin ismi fiile bağlamadığını açık bir şekilde ifade etmektedir. İlgi ekinin ikinci derecede bir hâl eki olduğunu söyleyen ve diğer hâl eklerinden çok farklı olduğuna dikkat çeken Ergin'e göre, bütün hâl ekleri ismi fiile bağladığı hâlde ilgi eki ismi isme bağlar. Bu sebeple bu ek, gerçek bir hâl eki karakterinde değil, iyelik ekleri tipinde bir ek durumundadır. Bir fiil grubu veya cümle eki değil, isim grubu eki olarak kullanılan bu ekin hâl ekliği sadece ileriye doğru ilişki kurmaktan, ismi kendisine tabi olmayan unsurlara bağlamaktan ibaret kalmaktadır. İlgi ekinin "ol-" fiili ve "-DXr" bildirme ekiyle kullanılması, bu ekin ismi fiile bağladığı görüntüsü vermektedir. Fakat ekin birinci işlevine dayanan bu işlevinde gizli olarak bağlı olduğu bir isim ifade edilmekte, o isim zikredilmediği için fiile bağlanıyor görüntüsü vermektedir (Ergin 1993:217-219). Bu durumu dile getiren dilcilerden biri de Zeynep Korkmaz'dır. Korkmaz'a göre ilgi eki bazı fiiller ve "DXr" bildirme ekiyle kullanılarak isimleri fiile bağlar. "Şu ikisi sen+in şu ikisi de onların sayılır.", "El+in+deki Ali'nindir." gibi. Burada "senin, onlarm, Ali'nin" gibi isimler yanında anlamca bilinmekle birlikte söylenmemiş ve gizli kalmış birer isim bulunduğu için "senin payın, onların payı, Ali'nin kitabı gibi" dolayısıyla ilgi durumu şeklen bir fiile bağlanmış görünse de aslında yine ismi isme bağlayan bir işlev yüklenmiştir (Korkmaz 2003:270). İlgi ekinin "ol-“ fiili ve “$D X r$ " bildirme ekiyle kullanılmasının genellikle bu ekin hâl eki olarak değerlendirilmesine sebep olarak gösterildiğini söyleyen Buran, bu durumun söz konusu fiilin özel durumu ile ekin yapısından kaynaklandığını belirtir (Buran 2011:381). Dolayısıyla ilgi eki, ismi tabi olduğu başka bir isme bağlar ve ismi hiçbir şekilde doğrudan fiile bağlamaz.

Ergin, bu ekin zamirleri bazı edatlara bağladığını, dolayısıyla bunun onları fiillere bağlamak olduğunu söyler. Ancak ilgi eki burada eklendiği zamirleri fiile değil, edatlara bağlamaktadır. Bu kullanımlarda edatlar kaldırılırsa zaten bağlamanın mahiyeti ortaya çıkar ve ilgi ekinin eklendiği ismi fiile değil, edatlara bağladığı apaçı meydana çıkar: "Bugün benim için şarkı söyle. > Bugün benim şarkı söyle." Velevki dolayısıyla fiillere bağlamak söz konusu olsun hâl ekleri ismi doğrudan fiile bağladıkları için ilgi eki yine de hâl eki sayılamaz. Bütün bunlar dikkate alındığında ilgi ekinin eklendiği isimleri doğrudan fiillere bağlamak gibi bir işlevinin olmadığı söylenebilir.

\section{Kategorik Durumu}

İlgi ekinin kategorik durumunun tayini konusunda da dilciler arasında fikir birliği bulunmamaktadır. Bu ekin kategorik durumu ile ilgili tartışmalar daha çok ekin hâl eki olup olmadığı konusunda yoğunlaşmaktadır. Çoğu dilci ilgi ekini tereddütsüz hâl eki kabul etmekte, yayınlarında hâl ekleri arasında değerlendirmektedir. Bazı dilciler ise ilgi ekini hâl eki olarak kabul etmeyerek isim çekim ekleri başlığı altında ele almaktadır. Her iki görüşteki dilciler, genellikle, tanımdan yola çıarak veya ekin farklı işlevlerini esas alarak ilgi ekinin kategorik durumunu tayin etmeyi tercih etmektedirler.

Dilbilgisi kitaplarında ilgi eki genellikle isim çekim ekleri başlığı altında ismin hâl ekleri 
içerisinde gösterilmektedir. Birçok dilci, hâl kategorisininin sadece isimle fiil arasında ilişki kurmaktan ibaret olmadığı, aynı zamanda isim ile isim soylu diğer kelimelerle ilişkisini de belirleyen bir kategori olduğu görüşündedir. Bu görüşü savunan dilciler, ismi isme ve zamirleri bazı edatlara bağlayan ilgi ekini hâl eki saymışlardır (Lübimov 1959:408-412; Ergin 1993:218; Korkmaz 2003:23; Banguoğlu 2000:328; Koç 1996: 70; Eker 2006: 370; Hengirmen 2007:125; Topaloğlu 1989:89; Vural-Böler 2014:151; Özçelik- Erten 2000:116; Börekçi 2007:245-276; DemirYılmaz 2005: 97; Üstünova 2008: 69-72; İpek 2008: 65; Karaağaç, 2012: 334). Bu dilcilerden Börekçi (2007:245-276) ve Üstünova (2008: 69-72), ilgi eki ile birlikte iyelik eklerini de hâl kategorisinde değerlendirmişlerdir. İlgi ekinin hâl eki olduğunu savunan dilcilerin çokluğu ilgi ekinin bu şekilde kategorize edilmesine yol açmış ve ilgi eki, "ilgi hâli/durumu eki" olarak ifade edilmiştir.

İlgi ekine "belirten durumu" diyen Kahraman, ismi isme bağlamanın yanısıra ismi fiile de bağlayan bu ekin hâl eki sayılması gerektiğini belirtir (Kahraman 2011:396). İlgi ekini eklendiği isim ile başka bir isim arasında sahiplik, ilgi bağı kurma durumu olduğunu söyleyen Korkmaz'a göre, diğer hâl eklerinden farklı olarak ismi fiile bağlamayan ilgi ekini isimler arasında ilişki kuran bir ek olduğu için hâl eki saymamak doğru değildir. İsimler arasında ilişki kurmak da çekim basamaklarından biri olarak kabul edilmelidir (Korkmaz 2003:269-270). İlgi ekini, ismi tabi olduğu başka bir isme bağlayan ek olarak tanımlayan Ergin'e göre, bu ek ismi tabi olduğu başka bir isme bağladığı hâldir. Bu sebeple anlam ilgisi içerisinde yan yana getirilen isimler ilgi eki almadan eksiz ilgi hâlinde bulunabileceği gibi ilgi eki alarak ekli şekilde de ilgi hâlinde bulunabilirler (Ergin 1993:218).

Ekleri; yapım ekleri, çekim ekleri, fiilimsiler, çatı ekleri, olumluluk-olumsuzluk ekleri, teklik-çokluk eki, soru eki, sıfatlama eki olmak üzere sekiz sınıfa ayıran Turan, ilgi ekini hâl ekleri içerisinde değerlendirmiştir (Turan 2007: 1845-1852). Üstünova, çekim/işletim ekleri ile ilgili mevcut tasnifleri değerlendirdikten sonra ilgi ekini iyelik ekleri ile birlikte "Adı Ada Bağlayan Ad İşletme Ekleri" bağllğında göstermiş ve "Tamlayan Durumu" kategorisinde değerlendirmiştir (Üstünova 2008:69-72). İşlevden yola çıkarak hâl kategorisini sınıflandıran Börekçi, ilgi ekini diğer hâl ekleriyle birlikte "İsimlerle İsimler Arasında Tamlama İlişkisi Kuran Hâller" bağlığında "Tamlayan Hâli” olarak göstermiştir (Börekçi 2007:245-276).

Bazı dilciler ise, hâl kavramını, isimle fiilin ilişkisiyle sınırlandırdıkları için sadece isimle fiil ilişkisi kuran yalın, yönelme, belirtme/yükleme, bulunma ve çkma hâlleri kabul etmişlerdir (Ediskun 2010:110-114; Bilgegil 2009:172; Gencan, 1979: 155; Demiray 1991:105). Bu hâller dışında başka hâller kabul eden fakat ilgi ekini hâl eki olarak kabul etmeyen dilciler de vardır (Gülsevin 2004:1267-1283; Buran 2011:381; Delice 2000:221-235; Karahan 1999:610).

Yaptı̆̆1 ek tasnifinde çekim ekleri diye bir kategori belirlemeyen ve ekleri; genişletme ekleri, durum ekleri, kurucu ekler, dönüştürücü ekler, yapım ekleri, bütünleşik ekler, temsil ekleri olmak üzere yedi gruba ayıran Delice, isim çekim eklerinden ilgi ve iyelik eklerini diğer öbek kurucu eklerle beraber, eklendikleri kelimeleri anlam ve tür olarak değistirmeksizin diğer bir kelimeye anlamsal açıdan tamamlayıcı olarak bağlamaya ve kelime öbeği yapmaya yarayan ekler şeklinde tanımladığı "Kurucu Ekler" başlığı altında ele almayı tercih etmiştir (Delice 2000:221-235). Delice, bu tasnifiyle ilgi eki, iyelik ekleri ve diğer öbek kurucu ekleri çekim eklerinden çok yapım eki sayma eğiliminde görünür.

Türkçe eklerin, önce yapım ekleri ve çekim ekleri olarak iki gruba; bunların da kendi içlerinde alt gruplara ayrılması şeklinde yapılan tasniflerin ihtiyaca cevap vermekten uzak olduğunu söyleyen Gürer Gülsevin, eklerin türetme ekleri, tür/görev değiştirici ekler, işletme ekleri ve kategori ekleri olarak dört gruba, bunların da kendi aralarında alt gruplara ayrılması 
gerektiğini belirtir. İlgi ekini işletme ekleri arasında sayan Gülsevin, isimlerde hâl ekleri, ilgi ve iyelik ekleri; fiillerde çatı, kip, bildirme ve kişi eklerinden oluşan işletme eklerini; sözlüksel kelime türetmeyen, kelime türünü değiştirmeyen, cümledeki kelime ve kelime grupları arasında ilişki kuran ekler olarak tanımlar (Gülsevin 2004:1267-1283).

Yükleme hâli ekinin bazı dönemlerde ilgi hâli eki yerine kullanıldığını ve bu iki ek arasındaki işlev paralelliğinin bu ekleri biribirine yaklaştırdığını söyleyen Karahan'a göre, "belirtme" görevi yapan ve işlevleri eklendikleri kelimelerle sınırlı olan yükleme ve ilgi hâli ekleri, diğer hâl ekleri gibi ileriye doğru münasebetler kuran ekler değildir. Yükleme hâli eki, nesne yapıcı değil, var olan nesneye belirlilik kazandıran bir ek; ilgi hâli eki de isme belirtme, sahiplik, mensubiyet, ilgi vb. anlamlar kazandıran bir ektir. Bu sebeple hâl ekleri değerlendirilirken, bu iki ekin de başka kelimelerle münasebet kuran ekler olmadıkları noktasından hareketle diğer hâl eklerine benzemedikleri hususu göz önünde bulundurulmalı ve bu iki ek hâl kategorisi içinde değil, ayrı bir kategori içinde işlenmelidir (Karahan 1999:610).

İsmin fiile göre durumunu belirlemediği için diğer hâl ekleriyle işlev farklılığ ${ }_{1}$ olan ilgi ekinin hâl eki olmadığını söyleyen Buran'a göre, birçok dilci tarafından hâl ekleri arasında gösterilmesine rağmen ismi fiile doğrudan bağlamayan, isim ile isim arasında bir ilgi kuran tek hâl eki, ilgi ekidir. İlgi eki, ismin fiile göre durumunu belirlemediği için hâl eki sayılmamalıdır. Ekin sadece "ol-" fiili ve "-DXr" bildirme ekiyle birlikte kullanılması bu fiilin ve ekin özel yapısından kaynaklanmaktadır (Buran 2011:381).

İyelik ekleriyle bağlantılı olarak ilgi ekinin kategorik durumunu ele alan Karademir'e göre, şayet ismin isimle ilişkisi hâl kategorisinde değerlendiriliyor ve buna binaen ilgi eki hâl eki sayılıyorsa, sözdizimsel yapıda onunla birlikte isim tamlaması oluşturan iyelik eklerinin durumu da bu açıdan gözden geçirilmelidir. Zira ilgi ekinin isim hâl ekleri kategorisinde değerlendirilip onunla birlikte tamlama oluşturan iyelik eklerinin hâl kategorisinde değerlendirilmemesi çelişkili bir durum arz etmektedir. Bu sebeple işlevlerine göre ele alındığında ilgi ekinin isim çekim ekleri içerisinde iyelik ekleriyle birlikte ismi isme bağlayan ekler olarak değerlendirilmesi doğru bir yaklaşım olacaktır (Karademir, 2013:174).

İlgi ekinin kategorik durumunun belirlenmesindeki fikir ayrılıklarının bir kısmı bu ekin farklı şekilde tanımlanmasından, önemli bir kısmı da tasnif yapılırken farklı işlevlerinin esas alınmasından kaynaklanmaktadır. Bu konuda öncelikle ek tasniflerinin hangi işleve göre yapılması gerektiği hususunda bir karar vermek gerekir. Aslında bu konuda tek seçenek vardır. $\mathrm{O}$ da eklerin varlık sebebi olan esas işlevlerine göre tasnif edilmesidir. Diğer işlevleri dilin işleyişi içerisinde zamanla kazanılmış işlevlerdir. Eklerin kategorik durumları esas işlevine göre tayin edilmediği takdirde hem yapılan tasnifler sağlıklı olmaz hem de bu tasniflerde belirlenen kategorik durum tayinlerinde fikir birliği sağlanması zorlaşır.

İlgi ekinin kategorik durumunun belirlenmesinde farklı işlevlerin esas alınması karışık bir durum ortaya çıkarmıştır. Hatta bazı dilciler bırakın farklı işlevleri esas alarak benzerlik bulmak, işlev yönünün benzerliğini yeterli görerek bu durumu ilgi eki ile hâl ekleri arasındaki benzerlik saymış ve ilgi ekinin hâl eki sayılmasının sebeplerinden biri olarak görmüştür (Ergin 1993:217; Kahraman 2011:396). Bu konuyu "Türkiye Türkçesinde İyelik Olgusu" adlı kitabında iyelik eki bağlamında tartışmaya açan Karademir, bu konudaki tartışmalara noktayı koymuştur. Dilcilerin bir kısmının ilgi ekleri de dâhil, hâl eklerinin ileriye/dışa dönük; iyelik eklerininse geriye/içe dönük ekler olduğunu gerekçe göstererek ilgi ekini hâl kategorisinde saydığını ancak iyelik eklerini saymadığını söyleyen Karademir, birbirini bütünleyen, birinin eksikliği diğerini doğrudan ilgilendiren eklerin farklı kategorilerde değerlendirilmesinin isim hâli tanımlarında yer almayan bir gerekçeye dayanan çelişkili bir yaklaşım olduğunu söyler. Şayet hâl kavramı, isimle ismin münasebetinde de söz konusu ise ve bu gerçekten hareketle ilgi 
eki, isim hâli kategorisinin elemanı sayılıyorsa; o zaman iyelik eklerinin de isim hâli kategorisinde sayılması gerektiğini belirten Karademir'e göre, iyelik eklerinin yönünün geriye dönük olması, onların durum ekleri olmadıkların değil, tersine münasebet kurucu birimler olduklarını, geldikleri adları başka adlara karşı bir duruma soktuğunu gösterir. Yönün geriye dönük olması, içe dönük olmasıyla da karıştırılmamalıdır (Karademir, 2013:173).

Ekler dilin işleyişi içerisinde zamanla kazanılmış işlevlerine göre değil, varlık sebepleri olan esas işlevlerine göre tasnif edilmelidir. Bu şekilde tasnif yapıldığı takdirde hem sağlıklı sonuçlar elde edilir hem de karışıklığın önüne geçilmiş olur. Aksi takdirde herkes farklı işlev veya işlevlere göre tasnif yapar ve ortaya büyük bir karışıklık çıkar. Bir ekin hâl eki olabilmesi için bu eklerin asıl işlevi olan isimleri fiile bağlama işlevini yerine getirmesi gerekir. Eğer esas işlevi dikkate alınarak hâl ekleri, "esas işlevi isimleri fiillere bağlamak olan, ayrıca isimleri isimlere bağlayan ekler" olarak değerlendirilirse ilgi eki hâl eki değildir.

Fakat esas işlevi göz ardı edilerek ismi isme bağlayan ekler hâl eki olarak kabul edilirse o zaman ilgi ekinin yanı sıra bu ek gibi ismi isme bağlayan iyelik ekleri de hâl eki sayılmalıdır. Halbuki ilgi ekini hâl eki olarak gören dilcilerden Börekçi (2007:245-276) ve Üstünova (2008: 6972) dışında iyelik eklerini hâl eklerinden sayan dilci yoktur. İyelik ekleri hâl eki kabul edilmediğine göre onlar gibi esas işlevi ismi isme bağlamak olan ve eklendiği isimleri hiçbir şekilde doğrudan fiile bağlamayan ilgi eki de hâl eki değildir.

Yukarıdaki bilgiler değerlendirildiğinde; gerek geleneksel gerekse yeni ek tasniflerinde ilgi ekinin yapım eki olmadığı konusunda görüş birliği olduğu ve bir istisna dışında (Delice 2000:221-235) dilcilerin ilgi ekini çekim/işletim/işletme ekleri içerisinde değerlendirdiği söylenebilir. Delice, ilgi ekini çekim/işletim eklerinden bağımsız, ayrı bir başlıkta; ilgi ekini hâl eki olarak kabul edenler, bu eki, çekim/işletim ekleri başlığı altında hâl ekleri içerisinde; ilgi ekini hâl eki kabul etmeyenler ise, ilgi ekini iyelik ekleri, hâl ekleri ve çokluk ekiyle birlikte çekim/işletim ekleri içinde değerlendirmiştir.

İlgi ekinin kategorik durumunun doğru belirlenmesi ve bu konudaki fikir ayrılıklarının giderilebilmesi için tasnif yapılırken diğer eklerle beraber bu ekin de esas işlevi dikkate alınmalıdır. İlgi ekinin esas işlevi eklendiği ismi başka bir isme bağlamak; hâl eklerinin esas işlevi ise eklendiği ismi fiile bağlamaktır. Bu sebeple esas işlevi eklendiği ismi başka bir isme bağlamak olan ilgi eki, isim çekim ekleri içerisinde esas işlevi eklendiği ismi fiile bağlamak olan hâl ekleriyle değil, kendisi gibi esas işlevi ismi isme bağlamak olan iyelik ekleriyle birlikte "İsmi İsme Bağlayan Ekler" olarak değerlendirilmelidir.

\section{SONUÇ}

Bugüne kadar ilgi eki için, ne ifade ettiği pek anlaşılmayan "türlük düşüm", Türkçe olmayan "genitif (hâli)", bu ekin bir görevini yansıtan "tamlayan durumu" ve "belirten durumu", iyelik ekleriyle karıştırılmasına sebep olan "iyelik hâli", eklendiği isimlere kattığı anlamı gösteren "katılma/kimin hâli", ekin sekiz şeklinden sadece birini yansıtan "-in hâli" ve bilimsel dayanağı olmadan bu eki peşinen hâl kategorisine sokan "ilgi hâli/durumu" gibi çeşitli terim adları kullanılmıştır. Bu terim adlarından "ilgi hâli/durumu" terimi yaygınlık kazanmıştır. Fakat terim, yabancı dillerin ve dilbilgisi kurallarının etkisiyle "hâl/durum" ibaresiyle kullanılmaktadır.

Sadece "ilgi hâli/durumu eki" teriminde değil, bunun dışındaki "belirten durumu", "tamlayan durumu", "-in hâli", "kimin hâli" ve "katılma hâli" gibi terim adlarında da "hâl" veya "durum" ibareleri yer almaktadır. İlgi ekinin hâl eki olarak peşinen kabullenildiğini gösteren bu durum, bilimsel bir yaklaşım değildir. Mantığını açıklamadan ilgi ekinin hâl eki 
olduğunu kabul etmek dile ve bilime hizmet etmez. İsmi yükleme bağlayan ekler için "hâl veya durum eki" tabiri kullanılması doğaldır. Ancak bu tabirin ismi fiile değil, isme bağlayan bir ek için kullanılması izah gerektirir. Bugün dilcilerce hâl eki olarak kabul edilen dokuz ekten sadece bir tanesinin esas işlevi, eklendiği isimleri fiillere değil isimlere bağlamaktır. Bu ek de ilgi ekidir. Bu sebeple hâl eki olmadığı ortada olan ilgi ekinin "ilgi hâli/durumu eki" terimi ile adlandırılması doğru değildir. Bu sebeple bu ek için "ilgi eki" terimini kullanmak daha uygun olacaktır.

Dilciler, ilgi ekini hâl eki sayıp saymamalarına göre, genellikle önce hâl eki tanımını yapıp daha sonra ilgi eki tanımını da buna uydurmuşlardır. Bu sebeple hâl kavramı ve eklerinin doğru tanımlanması, ilgi ekinin tanımı için de önemlidir. Bugüne kadar yapılan hâl eki tanımlarında bu eklerin esas işlevi yerine eklendiği isimleri isim ve fiillere bağlamaları bağlamaları ön plana çıkarılınca ismi isme bağlayan eklerden ilgi eki hâl eklerine dâhil edilmiş fakat iyelik ekleri dâhil edilmemiştir. Çelişki oluşturan bu durumun ortadan kalkması ve hâl eklerinin doğru tanımlanabilmesi için bunların, varlık sebebi olan esas işlevine göre tanımlanması gerekir. Yapılan tanımda bu husus vurgulandığı takdirde hâl kavramının kapsamı belirlenir ve bu kapsama giren ve girmeyen ekler daha doğru bir şekilde tespit edilebilir. Bütün bu veriler ışığında hâl kavramı, "fiile doğrudan bağlanan isimlerin bu bağlanma esnasında içinde bulundukları durum" şeklinde; hâl ekleri ise, "esas işlevi isimleri fiile bağlamak olan, aynı zamanda isimleri isimlere ve bazı edatlara bağlayan ekler" şeklinde tanımlanabilir. Hâl kavramı ve ekleri bu şekilde tanımlandığında ilgi eki, fiili doğrudan ilgilendirmediği ve esas işlevi isimleri fiile bağlamak olmadığı için hâl kapsamı dışında kalır.

İlgi eki, bugüne kadar genellikle "ismi isme bağlayan ek", "ismi başka bir kavrama bağlayan ek" veya "bir kavramın başka bir kavrama bağlandığını gösteren durum" şeklinde tanımlanmıştır. Bu tanımlar ekin kapsamını net olarak yansıtmadığı için bu ekin tanımı ve kategorik durumu ile ilgili karışık bir durum ortaya çıkarmıştır. İlgi ekinin tam ve doğru şekilde tanımlanması ve bu ekin hâl eki olup olmadığı konusunda daha doğru bir kanıya varabilmek için esas işlevinin dikkate alınarak tanımlanması gerekir. Bu şekilde yapılacak tanım, ayrıca ilgi ekini tam olarak yansıtmalı, hâl ve iyelik eklerini dişarda bırakmalıdır. İlgi eki; "esas işlevi eklendiği ismi kendisinden sonraki isimlere bağlamak olan, aynı zamanda bazı edatları zamirlere bağlayan isim çekim eki" ş̧eklinde tanımlandığında, bu tanım hem ilgi ekini tam olarak ifade eder hem de hâl ve iyelik eklerini dışarıda bırakır. Çünkü hâl eklerinin esas işlevi isimleri kendisinden sonraki isimlere bağlamak değil, isimleri fiile bağlamaktır. İyelik ekleri ise, zamirleri edatlara bağlamaz.

İlgi ekinin biri, eklendiği ismi kendisinden sonraki isim veya isimlere bağlamak; diğeri, zamirleri bazı edatlara bağlamak olmak üzere iki işlevi vardır. Birinci işleviyle isim tamlaması, ilgi grubu ve deyimler kurar. Bu işlevde ekli olarak kullanıldı̆̆ gibi eksiz olarak da kullanılabilir. İkinci işleviyle ise, edat grubu kurar. Bu işlevler dışında ilgi ekinin, ismi fiile bağlamak şeklinde bir işlevinin olduğu iddia edilse de bu doğru değildir. Çünkü ilgi eki hiçbir zaman eklendiği isimleri doğrudan fiile bağlamaz. Bu ekin "ol-" fiili ve "-DXr" bildirme ekiyle kullanılması, söz konusu fiil ve ekin özel durumundan kaynaklanmaktadır. Bu tür kullanımlarda ilgi eki alan isimler, "ol-" fiili ve "-DXr" bildirme eki almış tamlananı düşmüş/düşürülmüş isim tamlamalarından oluşmaktadır. Burada ilgi eki alan isim, aldığı ilgi ekiyle ek fiile değil, düşen tamlanana bağlanır. Tamlanan düştüğü ya da düşürüldüğü için bu yapı, ismin ilgi ekiyle "ol-" fiili veya "-DXr" bildirme ekine doğrudan bağlandığı şeklinde bir görüntü vermektedir. Ekin birinci işlevine dayanan bu kullanımında ilgi eki alan ismin gizli olarak bağlı olduğu bir isim ifade edilmekte, bu isim düştüğü/düşürüldüğü için ilgi eki alan isim fiil veya bildirme ekine bağlaniyor görüntüsü vermektedir. Bu yüzden ismi tabi olduğu başka bir isme bağlayan ve ismi hiçbir şekilde doğrudan fiile bağlamayan ilgi ekinin ismi fiile 
bağlamak şeklinde bir işlevi yoktur.

Kategorik durumu ile ilgili tartışmalar daha çok ekin hâl eki olup olmadığı konusunda yoğunlaşan ilgi ekini, çoğu dilci tereddütsüz hâl eki kabul edip isim çekim eklerinden hâl ekleri içerisinde değerlendirirken bazı dilciler hâl eki olarak kabul etmeyerek iyelik ekleri, çoğul eki ve hâl ekleriyle beraber isim çekim ekleri başlığı altında ele almaktadır. Bu karışık durum, kategorik durumunun belirlenmesinde ekin esas işlevi yerine farklı işlevlerinin esas alınmasından ortaya çıkmıştır. Hatta bazı dilciler farklı işlevleri esas alarak benzerlik bulmanın da ötesine geçerek işlev yönünün benzerliğini esas alıp bu durumu ilgi eki ile hâl ekleri arasında benzerlik saymış ve bu ekin hâl eki sayılmasının sebeplerinden biri olarak görmüştür. $\mathrm{Bu}$ farklı yaklaşımlar ilgi ekinin kategorik durumunu netleştirmek yerine bu konuyu bir gramer sorunu hâline getirmiştir.

Ekler dilin işleyişi içerisinde zamanla kazanılmış işlevlerine göre değil, varlık sebepleri olan esas işlevlerine göre tasnif edildiğinde kategorik durumları daha doğru belirlenebilir. Aksi takdirde yapılacak tasnifler sağlıklı olmayacağı gibi, bu tasniflerle belirlenecek kategorik durum tayinleri hakkında fikir birliği sağlanması da zorlaşır. İlgi ekinin kategorik durumunun doğru belirlenmesi ve bu konudaki fikir ayrılıklarının giderilebilmesi için tasnif yapılırken diğer eklerle beraber bu ekin de esas işlevi dikkate alınmalıdır. Bu şekilde bir yaklaşım sergilendiğinde esas işlevi eklendiği ismi başka bir isme bağlamak olan ilgi eki ile esas işlevi eklendiği ismi fiile bağlamak olan hâl ekleri aynı kategoride değerlendirilemez. Bu sebeple ilgi eki, isim çekim ekleri içerisinde, esas işlevi eklendiği ismi fiile bağlamak olan hâl ekleriyle değil, kendisi gibi esas işlevi ismi isme bağlamak olan iyelik ekleriyle birlikte "İsmi İsme Bağlayan Ekler" olarak aynı kategoride değerlendirilmelidir. 


\section{KAYNAKÇA}

ADALI, Oya (2004), Türkiye Türkçesinde Biçimbirimler, İstanbul: Papatya Yayınları.

AKSAN, Doğan (1998), Her Yönüyle Dil Ana Çizgileriyle Dilbilim, , Ankara: TDK Yayınları.

BANGUOĞLU, Tahsin (1940), Anahatlarıla Türk Grameri, İstanbul.

BANGUOĞLU, Tahsin (1959), Türk Grameri-Ses Bilgisi, Ankara.

BANGUOĞLU, Tahsin (1974), Türkçenin Grameri, İstanbul.

BANGUOĞLU, Tahsin (2000), Türkçenin Grameri, Ankara: TDK Yayınları.

BİLGEGİL, M. Kaya (2009), Türkçe Dilbilgisi, Erzurum: Salkımsöğüt Yayınevi.

BOZŞAHiN, Cem (1997), “Türkçedeki Durum Eklerinin Ulamsal Bir İrdelemesi”, 11. Dilbilim Kurultayi: Bildiriler ( ODTÜ, 22-23 Mayıs 1997,) Ankara, s.61-69.

BÖREKÇİ, Muhsine (2007) Türkçede Hâl Eklerinin İşlevsel Olarak Sınıflandırılması Üzerine Bir Deneme" IV. Uluslararası Türk Dili Kurultayı Bildirileri (24-29 Eylül, Çeşme) Türk Dil Kurumu Yayınları, Ankara, s.245-276.

BURAN, Ahmet (1995), "Türkçede İsim Çekim Ekleri”, Fırat Üniversitesi Sosyal Bilimler Dergisi, C. 7, S. 1-2, Elazığ, s. 37-48.

BURAN, Ahmet (2011), “Türkçede İsim Çekimi Ekleri” Türk Gramerinin Sorunları Bildiriler, Ankara: TDK Yayınları.

DELİCE, H. İbrahim (2000), "Türk Dilinde İşlevsel Ek Tasnifi Denemesi”, Cumhuriyet Üniversitesi Sosyal Bilimler Dergisi, S.24, Sivas, s.221-235.

DEMIR, Nurettin, Emine YILMAZ(2005), Türk Dili El Kitabı, Ankara: Grafiker Yayınları.

DEMiRAY, Kemal (1991), Temel Dilbilgisi, İstanbul: İnkılâp Kitabevi.

EDİSKUN, Haydar (2010), Türk Dilbilgisi, İstanbul: Remzi Kitabevi.

EKER, Süer(2006) Çă̆daş Türk Dili, Ankara: Grafiker Yayınları.

EMRE, Ahmet Cevat, (1945) Türk Dilbilgisi, İstanbul.

ERGİN, Muharrem (1993), Türk Dil Bilgisi, İstanbul: Bayrak Yayınları.

GENCAN, Tahir Nejat(1979) , Dilbilgisi, Ankara: TDK Yayınları.

GÜLSEVIN, Gürer (2004), “Türkçede 'Sıra-dışı' Ekler ve Eklerin Tasnif - Tanımlanma Sorunu Üzerine”, V. Uluslararası Türk Dili Kurultayı Bildirileri I, TDK Yayınları, Ankara 20-26 Eylül 2004, s.1267-1284.

HATiPOĞLU, Vecihe (1972), Dilbilgisi Terimleri Sözlüğ̈̈, Ankara: TDK Yayınları.

HENGiRMEN, Mehmet (1999) Dilbilgisi ve Dilbilim Terimleri Sözlüğ̈̈, Ankara: Engin Yayınları.

HENGİRMEN, Mehmet (2007), Türkçe Dilbilgisi, Ankara: Engin Yayınevi.

IPEK, Birol (2008) “Türk Dilinde Vasıta Hâli”, Türkiyat Araştırmaları Dergisi, S.23, s.63-97.

KAHRAMAN, Tahir (2003), "Dilbilgisi Derslerinde Ad Çekimlerinin İşlenişi Üzerine”, Çă̆daş Türk Dili, Ankara, C.16, S.187, s. 308-309.

KAHRAMAN, Tahir (2011), “Çağdaş Türkiye Türkçesinde Ad Çekimi Eklerinin Kullanım Özellikleri ve İşlevleri” Türk Gramerinin Sorunları Bildiriler, Ankara: TDK Yayınları.

KALKAN, Uğur (2006) Türkiye Türkçesinde Hâl (Durum) Kavramı ve Hâl (Durum) Eklerinin İşlevleri, Yayımlanmamış Yüksek Lisans Tezi, (Danışman: Doç. Dr. Erdoğan BOZ) Afyonkarahisar.

KARAAĞAÇ, Günay (2012), Türkçenin Dil Bilgisi, Ankara: Akçağ Yayınları.

KARADEMIR, Fevzi (2013), Türkiye Türkçesinde Iyelik Olgusu, İstanbul: Kesit Yayınları.

KARAHAN, Leyla (1999), “Yükleme(Accusative) ve İlgi Genitive Hali Ekleri Üzerine Bazı Düşünceler", III. Uluslararası Türk Dili Kurultayı Bildirileri 1996, TDK Yayınları, Ankara, s. 605611.

KOÇ, Nurettin (1992) Açıklamalı Dilbilgisi Terimleri Sözlüğü, İstanbul: İnkılâp Kitabevi.

KOÇ, Nurettin(1996), Yeni Dilbilgisi, İstanbul: İnkılâp Yayınları.

KORKMAZ, Zeynep (2003), Türkiye Türkçesi Grameri (Şekil Bilgisi), Ankara: TDK Yayınları.

KORKMAZ, Zeynep (2010), Gramer Terimleri Sözlü̆̆̈̈, Ankara: TDK Yayınları.

LÜBIMOV, Konstantin (1959), “Türkçede Kaç İsim Hâli Var?”, Türk Dili, C. 8, S. 96, Ankara, s. 688690.

ÖZÇELIK, Sadettin- Münir ERTEN (2000), Türkiye Türkçesi Dilbilgisi, Diyarbakır.

ÖZKAN, Abdurrahman (1999), "Fiil Tamlayıcı İlişkisi ve Fiillerin İstem Değiştirmesi”, Arayışlar-İnsan Bilimleri Araştırmaları, S. 1, Isparta, s. 125-143.

ÖZKAN, Nevzat (2001), "Hâl Ekleri Kalıplaşmaları ve Sebepleri Üzerinde Bir Değerlendirme”, İlmi 
Araştırmalar Dil, Edebiyat, Tarih Incelemeleri, S.12, İstanbul, s. 153-165.

TIMURTAŞ, Faruk Kadri (1964) Osmanlıca Grameri, İstanbul.

TOPALOĞLU, Ahmet (1989), Dil Bilgisi Terimleri Sözlüğüu, İstanbul: Ötüken Yayınları.

TURAN, Zikri (2007) “Türkçenin Yapım ve Çekim Düzeninde Yer Alan Eklerin Sınıflandırılması Nasıl Olmalıdır?", IV. Uluslararası Türk Dili Kurultayı Bildirileri (24-29 Eylül, Çeşme) Türk Dil Kurumu Yayınları, Ankara, s.1845-1852.

UZUN, Nadir Engin (1998), Dilbilgisinin Temel Kavramları, Ankara: Türk Dilleri Araştırmaları.

ÜSTÜNOVA, Kerime (2008) Türkiye Türkçesi Ad Isşletimi, İstanbul: Kesit Yayınları.

VARDAR, Berke (2002), Açıklamalı Dilbilim Terimleri Sözlüğü, İstanbul: Multilingual Kitabevi.

VURAL, Hanifi- Tuncay BÖLER (2014), Ses ve Şekil Bilgisi, İstanbul: Kesit Yayınları. 